\title{
INDUKSI KETAHANAN TERHADAP PENYAKIT HAWAR DAUN BAKTERI PADA TANAMAN PADI DI LAPANGAN MENGGUNAKAN RIZOBAKTERI INDIGENOS
}

\author{
Andi Khaeruni ${ }^{1}$, Abdul Rahim², Syair ${ }^{1}, \&$ Adriani $^{2}$ \\ ${ }^{1}$ Jurusan Agroteknologi Fakultas Pertanian Universitas Halu Oleo (UHO), Kendari \\ ${ }^{2}$ Balai Proteksi Tanaman Pangan dan Hortikultura, Kendari \\ E-mail : akhaeruni@yahoo.com
}

\begin{abstract}
Induced resistance to bacterial leaf blight disease in rice field by indigenous rhizobacteria. Bacterial leaf blight is the most important disease on paddy at Southeast Sulawesi. Utilization of biological agents that induce plant resistance is an alternative tool to control bacterial leaf blight disease on paddy. The aim of the experiment was obtain rhizobacteria that were able to stimulate the growth of paddy plants as well induce plant resistance towards bacterial leaf blight in the field. All experiment units were arranged with a factorial design in a randomized complete block design. The first factor was the rhizobacteria isolates, consisting 4 treatments, i.e: without rhizobacteria (R0), isolate P11a (R1), isolate PKLK5 (IR2), and mixture P1 1a and PKLK5 (R3), the second factor is paddy varieties, (V1): IR64 variety, (V2): Cisantana variety. The pathogen was inoculated on leaf when 45 day after crop. Weekly observation of disease severity, vegetative plant growth (leaf and stem numbers), and yield were conducted. The results showed that the 10 isolates of rhizobacteria tested were able to induce plant resistance toward bacterial leaf blight, stimulated vegetative growth as well as increased yield of paddy plant. Rhizobacteria application could increase the resistance of paddy toward Xanthomonas oryzae pv. oryzae. The application rhizobacteria could increase the vegetative plant growth, application mixture P11a and PKLK5 isolates showed higher resistance than single application in terms of plant growth and yield, both IR64 and Cisantana varietes.
\end{abstract}

Key words: Bacterial leaf blight, induce resistance, rhizobacteria, paddy

\begin{abstract}
ABSTRAK
Induksi ketahanan terhadap penyakit hawar daun bakteri pada tanaman padi di lapangan menggunakan rizobakteri indigenos. Penyakit hawar daun bakteri yang disebabkan oleh Xanthomonas oryzae pv. oryzae merupakan penyakit penting tanaman padi sawah di Sulawesi Tenggara. Penggunaan agens hayati penginduksi ketahanan tanaman, merupakan salah satu alternatif yang dapat digunakan untuk mengendalikan penyakit hawar daun bakteri di lapangan. Penelitian ini bertujuan untuk mengetahui dan mengkaji kemampuan beberapa isolat rizobakteri yang mampu memacu pertumbuhan, meningkatkan hasil dan menginduksi ketahanan tanaman padi terhadap penyakit hawar daun bakteri. Penelitian menggunakan Rancangan Faktorial yang diatur dalam Rancangan Acak Kelompok. Faktor pertama adalah jenis rizobakteri (R), yang terdiri dari 4 taraf perlakuan yaitu: tanpa isolat rizobakteri (R0), isolat P11a (R1), isolat PKLK5 (R2) dan kombinasi isolat P11a dan PKLK5 (R3). Faktor kedua adalah varietas tanaman padi yaitu : varietas IR64 (V1) dan varietas Cisantana (V2). Patogen diinokulasi pada daun tanaman ketika berumur 45 hari setelah tanam. Keparahan penyakit dan jumlah anakan diamati pada umur pengamatan dua mingguan dilakukan untuk mengamati intensitas serangan penyakit hawar daun bakteri. Hasil penelitian menunjukkan bahwa perlakuan rizobakteri mampu menginduksi ketahanan tanaman padi IR64 dan Cisantana terhadap Xanthomonas oryzae pv. oryzae, perlakuan rizobakteri mampu meningkatkan pertumbuhan dan hasil tanaman padi di lapangan, perlakuan campuran rizobakteri PKLK5 dan P11a, cenderung meningkatkan induksi ketahanan padi varietas IR64 terhadap Xanthomonas oryzae pv. oryzae di lapangan dibandingkan perlakuan rizobakteri secara tunggal, perlakuan ini juga cenderung memperlihatkan pertumbuhan dan produksi tanaman yang lebih baik dibandingkan pada perlakuan rizobakteri secara tunggal baik pada varietas IR64 maupun Cisantana.
\end{abstract}

Kata kunci: hawar daun bakteri, induksi ketahanan, padi, dan rizobakteri 


\section{PENDAHULUAN}

Penyakit hawar daun bakteri (HDB) yang disebabkan oleh Xanthomonas oryzae pv. oryzae (Xoo) merupakan salah satu penyakit utama padi sawah di Indonesia (Hifni \& Kardin, 1998). Di Indonesia kehilangan hasil akibat penyakit ini dapat mencapai 30$50 \%$ khususnya pada varietas-varietas rentan seperti varietas IR64. Penyakit ini semakin berkembang jika pertumbuhan tanaman padi tidak optimal karena kondisi lahan yang kurang subur. Di Sulawesi Tenggara serangan Xoo telah dilaporkan di sentra pertanaman padi seperti di Kabupaten Konawe, Kolaka dan Konawe Selatan (Khaeruni \& Wijayanto, 2013).

Upaya pengendalian penyakit HDB yang umum dilakukan adalah penggunaan varietas tahan (Rao et al., 2003). Penggunaan varietas tahan ternyata belum memberikan hasil yang memuaskan karena Xoo mempunyai tingkat keragaman patotip yang tinggi yang disebabkan oleh faktor lingkungan, varietas yang digunakan dan tingkat mutabilitas gen yang tinggi (Keller et al., 2000). Hasil penelitian Rahim et al. (2012) menunjukkan bahwa dari enam varietas komersial yang diuji di lapangan, belum ada yang tahan terhadap Xoo, khususnya terhadap patotip IV. Oleh karena itu pengendalian hayati berupa penggunaan rizobakteri indigenos penginduksi ketahanan tanaman dapat dipertimbangkan sebagai alternatif pengendalian penyakit HDB yang ramah lingkungan.

Beberapa penelitian memperlihatkan bahwa penggunaan Plant Growth Promoting Rhizobacteria (PGPR) mampu memacu pertumbuhan tanaman sekaligus mengendalikan patogen tanaman sehingga mengurangi pemakaian senyawa kimia sintesis secara berlebihan, baik dalam penyediaan hara tanaman (biofertilizer) maupun dalam pengendalian patogen tanaman (bioprotectan) (Sutariati, 2006; Khaeruni et al., 2010). Rizobakteri selain mampu mengendalikan patogen tular tanah juga dilaporkan dapat menginduksi ketahanan tanaman terhadap penyakit virus dan penyakit filosfer lainnya. Hasil kajian Khaeruni et al.(2013) menunjukkan bahwa penggunaan rizobakteri isolat $\mathrm{P} 11 \mathrm{a}$ dan PKLK5 yang diisolasi dari pertanaman padi sehat mampu memacu pertumbuhan dan menginduksi ketahanan tanaman padi IR64 terhadap penyakit HDB pada skala rumah kasa. Pemanfaatan rizobakteri indigenos sebagai agensia pemacu pertumbuhan dan penginduksi ketahanan tanaman padi terhadap penyakit HDB di skala lapangan perlu dilakukan untuk dapat dijadikan acuan rekomendasi sebagai salah satu strategi pengendalian penyakit HDB pada tanaman padi di Sulawesi Tenggara.
Penelitian ini bertujuan untuk mengetahui dan mengkaji isolat yang mampu sebagai penginduksi ketahanan tanaman padi terhadap serangan Xoo penyebab HDB di lapangan.

\section{METODE PENELITIAN}

Tempat dan Waktu. Penelitian ini dilaksanakan di persawahan petani yang memiliki sejarah endemik penyakit HDB di Desa Puday Kecamatan Wonggeduku Kabupaten Konawe. Penelitian berlangsung pada bulan Maret sampai Juli 2013.

Rancangan Penelitian. Penelitian ini didesain menggunakan Rancangan Faktorial yang diatur dalam Rancangan Acak Kelompok. Faktor pertama adalah jenis rizobakteri $(\mathrm{R})$, yang terdiri dari 4 taraf perlakuan yaitu: tanpa isolat rizobakteri (R0), isolat P11a (R1), isolat PKLK5 (R2) dan kombinasi isolat P11a dan PKLK5 (R3). Faktor kedua adalah varietas tanaman padi yaitu: varietas IR64 (V1) dan varietas Cisantana (V2), sehingga terdapat 8 kombinasi perlakuan yang diulang sebanyak 3 kali sehingga diperoleh 24 unit petak percobaan.

Biopriming Benih dengan Rizobakteri. Tahapan ini dilakukan pada benih padi IR64 dan Cisantana dengan isolat rizobakteri P11a dan PKLK5 (koleksi Laboratorium Agroteknologi FP-UHO), dengan perlakuan sebagai berikut: sekitar 100 benih padi varietas IR64 dan Cisantana direndam selama 24 jam dalam suspensi jadi satu isolat murni rizobakteri (umur 48 jam) dengan konsentrasi $10^{8}-10^{9} \mathrm{cfu}$ per $\mathrm{ml}$ akuades steril. Benih yang telah diberi perlakuan biopriming terlebih dahulu diperam selama 2 hari hingga membentuk tunas kecambah. Benih selanjutnya disemai di bak-bak plastik ukuran $50 \times 35 \times 15 \mathrm{~cm}$ yang diisi dengan tanah bercampur pupuk kandang $(4: 1 \mathrm{v} / \mathrm{v})$ yang telah disterilkan.

Persiapan Lahan. Lahan terlebih dahulu diolah dengan traktor lalu diratakan dengan garuh dan dibuat petakan percobaan sebanyak 24 unit dengan ukuran $200 \mathrm{~cm}$ (p) x $150 \mathrm{~cm}$ (l) x $30 \mathrm{~cm}(\mathrm{t})$. Jarak antar petak dalam lajur yang sama $30 \mathrm{~cm}$ sedangkan jarak antar lajur $50 \mathrm{~cm}$.

Perlakuan dan Penanaman Bibit. Setelah berumur 21 hari, bibit dicabut dan dibersihkan perakarannya dari sisa tanah yang melekat lalu direndam dalam suspensi rizobakteri selama 30 menit. Sementara itu, bibit tanpa perlakuan rizobakteri hanya direndam dalam akuades steril dengan waktu yang sama. Setelah perendaman, 
bibit langsung ditanam (1 bibit perlubang sesuai perlakuan) dengan jarak tanam $20 \times 20 \mathrm{~cm}$.

Inokulasi Patogen. Isolat $X$. oryzae pv. oryzae yang digunakan dalam penelitian ini ialah patotipe IV hasil isolasi dari pertanaman padi di Sulawesi Tenggara (Koleksi Laboratorium IHPT UHO). Penyiapan dilakukan dengan mensuspensikan isolat murni $X$. oryzae pv. oryzae umur 48 jam dalam akuades steril dengan konsentrasi $10^{8} \mathrm{cfu}$ per ml. Inokulasi dilakukan pada tanaman yang berumur 45 hari setelah tanam dengan metode pelukaan dengan gunting yang telah dicelup dalam suspensi patogen.

Variabel Pengamatan. Pengamatan terhadap respon perlakuan ditentukan pada 5 rumpun tanaman yang menyebar secara diagonal pada setiap unit/petak perlakuan, sehingga secara keseluruhan terdapat 120 rumpun tanaman.

Intensitas Penyakit. Pengamatan dilakukan pada umur 2, 4 dan 6 minggu setelah inokulasi (MSI) pada 5 lembar daun pada 5 tanaman uji pada setiap unit perlakuan. Intensitas penyakit hawar daun bakteri dihitung menggunakan metode Abbot (1925) dalam Sudantha et al.,(2006) dengan menggunakan rumus:

$$
\mathrm{I}=(\mathrm{A} / \mathrm{B}) \times 100 \%
$$

dengan:

$\mathrm{I}=$ intensitas penyakit (\%)

$\mathrm{A}=$ panjang daun yang bergejala hawar pada daun sampel

$\mathrm{B}=$ panjang keseluruhan daun sampel

Jumlah Anakan. Jumlah anakan yang terbentuk diamati pada setiap tanaman sampel di setiap unit percobaan pada saat 2, 4, dan 6 minggu setelah tanam.

Hasil Panen. Hasil panen yang diamati meliputi jumlah malai, berat gabah kering panen dan berat gabah per 1000 butir.

Analisis Data. Data dianalisis dengan menggunakan analisis ragam, apabila dalam analisis ragam terdapat pengaruh nyata, maka dilanjutkan dengan Uji Jarak Berganda Duncan (UJBD) pada taraf nyata $\alpha=0,05$.

\section{HASIL DAN PEMBAHASAN}

Rekapitulasi hasil sidik ragam pemanfaatan rizobakteri sebagai penginduksi ketahanan tanaman padi terhadap serangan $X$. oryzae pv. oryzae dapat dilihat pada Tabel 1. Hasil sidik ragam menunjukkan bahwa perlakuan interaksi rizobakteri dan varietas padi memberikan pengaruh nyata terhadap variabel pengamatan yang diujikan, walaupun pada waktu

Tabel 1. Hasil sidik ragam pemanfaatan rizobakteri sebagai penginduksi ketahanan tanaman padi terhadap serangan Xanthomonas oryzae pv. oryzae

\begin{tabular}{|c|c|c|c|c|c|c|c|}
\hline \multirow{3}{*}{ No. } & \multirow{3}{*}{ Variabel pengamatan } & \multicolumn{6}{|c|}{ Perlakuan } \\
\hline & & \multicolumn{2}{|c|}{ Interaksi } & \multicolumn{2}{|c|}{ Varietas } & \multicolumn{2}{|c|}{ Jenis Isolat } \\
\hline & & $(\mathrm{V} * \mathrm{R})$ & Fhit & $(\mathrm{V})$ & Fhit & (R) & Fhit \\
\hline \multirow[t]{4}{*}{1.} & Intensitas penyakit & & & & & & \\
\hline & 59 HST & $*$ & 6,23 & $*$ & 5,47 & $* *$ & 9,01 \\
\hline & 73 HST & $\operatorname{tn}$ & 14,11 & $\operatorname{tn}$ & 2,14 & $* *$ & 31,71 \\
\hline & $87 \mathrm{HST}$ & $*$ & 42,12 & tn & 0,52 & $* *$ & 93,05 \\
\hline \multirow[t]{4}{*}{2.} & Jumlah anakan & & & & & & \\
\hline & $2 \mathrm{MST}$ & tn & 0,82 & tn & 0,06 & tn & 1,20 \\
\hline & $4 \mathrm{MST}$ & $*$ & 3,24 & $\operatorname{tn}$ & 0,01 & $*$ & 3,88 \\
\hline & $6 \mathrm{MST}$ & tn & 2,78 & tn & 0,16 & $*$ & 4,63 \\
\hline \multirow[t]{4}{*}{3.} & Produksi & & & & & & \\
\hline & Jumlah Malai & $* *$ & 37,34 & $* *$ & 70,84 & $* *$ & 35,29 \\
\hline & Berat Gabah Kering Panen & $* *$ & 8,83 & tn & 2,04 & $* *$ & 8,91 \\
\hline & Berat Gabah 1000 Biji & tn & 1,98 & tn & 0,05 & $*$ & 4,26 \\
\hline
\end{tabular}

tn = berbeda tidak nyata, $*$ = berbeda nyata, $* *=$ berbeda sangat nyata, HST $=$ hari setelah tanam, MST $=$ minggu setelah tanam 
tertentu terdapat interaksi yang tidak berbeda nyata. Perlakuan varietas secara mandiri umumnya tidak berbeda nyata, namun sebaliknya umumnya perlakuan rizobakteri secara mandiri memberi pengaruh yang nyata dan sangat nyata.

Intensitas Penyakit. Intensitas penyakit HDB pada setiap kombinasi perlakuan yang diujikan ditampilkan pada Tabel 2.Berdasarkan data pada Tabel 2, pada setiap waktu pengamatan intensitas penyakit pada perlakuan yang tidak menggunakan rizobakteri (V1R0 dan V2R0) selalu lebih tinggi dibandingkan pada perlakuan yang menggunakan rizobakteri. Intensitas serangan HDB terendah pada akhir pengamatan diperoleh pada perlakuan V1R3, walaupun tidak berbeda nyata dengan beberapa perlakuan lainnya. Hal ini mengindikasikan bahwa percampuran dua rizobakteri yang berbeda dapat meningkatkan ketahanan tanaman padi terhadap Xoo.

Hasil pengamatan di lapangan menunjukkan bahwa semua varietas padi yang diinokulasikan Xoo menunjukkan gejala penyakit hawar daun bakteri (HDB). Gejala ini ditandai dengan munculnya bercak memanjang dengan tepi bergelombang dari ujung daun yang berkembang sepanjang tepi daun kemudian berkembang menjadi hawar daun dan berubah warna menjadi kuning pucat (Liu et al., 2006; Agustiansyah, 2011).

Pengamatan penyakit hawar daun bakteri pada setiap perlakuan ditentukan berdasarkan pengamatan intensitas penyakit. Hasil pengamatan menunjukkan terjadi pengaruh pada setiap perlakuan pada umur 2, 4 dan 6 minggu setelah inokulasi (MSI). Varietas Cisantana dan IR64 yang tidak diberi rizobakteri selalu memperlihatkan intensitas penyakit yang lebih tinggi dibanding perlakuan tanpa rizobakteri. Hal ini menunjukkan bahwa tanaman padi yang diberi perlakuan rizobakteri memiliki ketahanan yang lebih baik. Perlakuan rizobakteri pada benih dan bibit sebelum tanam mampu menginduksi ketahanan tanaman secara sistemik terhadap serangan $X$. oryzaepv. oryzae.

Hasil pada Tabel 2 juga memperlihatkan bahwa pada pengamatan 6 MSI perlakuan campuran rizobakteri isolat PKLK5 dan P11a cenderung memperlihatkan tingkat intensitas serangan patogen lebih rendah dibanding dengan perlakuan rizobakteri secara tunggal khususnya pada varietas IR64, hal ini mengindikasikan bahwa pencampuran dua isolat yang berbeda cenderung meningkatkan induksi ketahanan sistemik tanaman padi terhadap $X$. oryzae pv. oryzae. Induksi ketahanan sistemik ialah fenomena terjadinya peningkatan ketahanan tanaman terhadap infeksi patogen setelah terjadi rangsangan dari luar. Ketahanan ini adalah perlindungan tanaman bukan untuk mengeliminasi patogen tetapi lebih pada aktivitas dari mekanisme pertahanan tanaman (Sticher et al.,1997; Van loon et al., 1998; Durrant \& Dong, 2004).

Hasil penelitian Hoerussalam et al. (2013) menjelaskan terjadi peningkatan status ketahanan tanaman jagung galur $\mathrm{C} 20$ terhadap penyakit bulai yang diinduksi dengan perendaman rizobakteri isolat Abio2 pada benih sebelum tanam. Keterjadian penyakit pada petak yang diberi perlakuan sebesar 6,25\% sementara yang tidak diberi kejadian penyakit bulainya mencapai $37,62 \%$, peningkatan ketahanan tanaman tersebut berkaitan dengan terjadinya peningkatan akumulasi asam salisilat di dalam jaringan tanaman, hal ini dibuktikan dengan terjadinya peningkatan kandungan asam salisilat

Tabel 2. Intensitas penyakit (\%) pada interaksi antar perlakuan pada setiap waktu pengamatan

\begin{tabular}{cccc}
\hline \multirow{2}{*}{ Perlakuan Interaksi } & \multicolumn{3}{c}{ Intensitas penyakit(\%) } \\
\cline { 2 - 4 } & 2 MSI & 4 MSI & $6 \mathrm{MSI}$ \\
\hline V1R1 & $8,3 \mathrm{bc}$ & $14,4 \mathrm{~b}$ & $22,9 \mathrm{c}$ \\
V1R2 & $8,7 \mathrm{abc}$ & $14,7 \mathrm{~b}$ & $19,1 \mathrm{~cd}$ \\
V1R3 & $8,4 \mathrm{bc}$ & $12,9 \mathrm{~b}$ & $18,3 \mathrm{~d}$ \\
V1R0 & $9,6 \mathrm{ab}$ & $23,8 \mathrm{a}$ & $34,6 \mathrm{~b}$ \\
V2R1 & $7,2 \mathrm{~cd}$ & $12,5 \mathrm{~b}$ & $18,6 \mathrm{~cd}$ \\
V2R2 & $5,6 \mathrm{~d}$ & $13,7 \mathrm{~b}$ & $18,8 \mathrm{~cd}$ \\
V2R3 & $7,6 \mathrm{bc}$ & $13,2 \mathrm{~b}$ & $19,7 \mathrm{~cd}$ \\
V2R0 & $10,5 \mathrm{a}$ & $21,5 \mathrm{a}$ & $40,5 \mathrm{a}$ \\
\hline
\end{tabular}

Angka yang diikuti huruf yang sama pada kolom yang sama menunjukkan tidak berbeda nyata berdasarkan uji Duncan $\alpha=0,05, \mathrm{~V} 1=$ varietas IR64, V2 = varietas Cisantana, $\mathrm{R} 0=$ tanpa isolat rizobakteri, $\mathrm{R} 1=$ isolat P11a, $\mathrm{R} 2$ $=$ isolat PKLK5, R3 = kombinasi isolate P11a dan PKLK5 
$0,074 \mu \mathrm{g}$ per g pada daun tanaman jagung yang memperlihatkan ketahanan terhadap penyakit bulai.

Jumlah Anakan. Hasil uji rataan jumlah anakan yang terbentuk pada setiap perlakuan disajikan pada Tabel 3 . Hasil uji pada Tabel 3, pada pengamatan 4 minggu setelah tanam (MST) memperlihatkan jumlah anakan tertinggi ditunjukkan pada perlakuan V1R3 dengan rata-rata 17,8 batang anakan. Pada pengamatan 6 MST perlakuan V1R3 dan perlakuan V2R1 juga masih memperlihatkan jumlah anakan yang lebih baik dibandingkan perlakuan lainnya, dengan jumlah anakan masing-masing 19,27 dan 20,00 batang anakan. Sementara anakan terendah diperlihatkan oleh kedua perlakuan yang tidak mendapat rizobakteri (V1R0 dan V2R0).

Hasil pengamatan pada Tabel 3 menunjukkan bahwa pada pengamatan 2 MST tidak memberikan pengaruh nyata terhadap semua perlakuan yang diujikan. Namun pada pengamatan 4 MST jumlah anakan tertinggi ditunjukkan pada perlakuan V1R3 yaitu dengan ratarata 17,8 batang yang berbeda sangat nyata dengan perlakuan tanpa isolat rizobakteri, sedangkan pada pengamatan $6 \mathrm{MST}$ jumlah anakan tertinggi diperlihatkan pada perlakuan Cisantana yang diinduksi dengan isolat P11a dengan rata-rata 20,00 batang anakan yang berbeda sangat nyata dengan perlakuan Cisantana tanpa induksi rizobakteri dengan jumlah anakan terendah yaitu rata-rata 14,9 batang. Hasil ini sejalan dengan penelitian Thakuria et al. (2004) menyatakan bahwa secara langsung rizobakteri berkemampuan dalam menyediakan dan memobilisasi penyerapan unsur hara dari dalam tanah, melarutkan fosfor dan menghasilkan hormon tumbuh sehingga dapat memacu pertumbuhan tanaman.
Pada tanaman yang diinokulasi $X$. oryzae pv. oryzae dengan pelukaan daun tanpa pemberian rizobakteri memungkinkan patogen dapat masuk dan menginfeksi jaringan tanaman dengan cepat sehingga dapat mengganggu metabolisme dalam sel dan jaringan tanaman yang berpengaruh terhadap pembentukan anakan dan jumlah daun. Kondisi inilah yang menyebabkan jumlah anakan pada perlakuan V1R0 dan V2R0 selalu lebih rendah dibanding perlakuan lainnya. Namun pada variabel pengamatan jumlah anakan, perlakuan campuran rizobakteri tidak berpengaruh terhadap peningkatan jumlah anakan di dua varietas padi yang diuji.

Hasil Panen. Hasil uji rataan hasil panen padi yang diujikan pada setiap perlakuan disajikan pada Tabel 4. Hasil uji pada Tabel 4, pengamatan jumlah malai tertinggi terdapat pada perlakuan V2R2 dengan nilai rata-rata 25,40 malai yang berbeda tidak nyata dengan perlakuan V1R3 dan berbeda nyata dengan perlakuan V2R1 dan V2R3, namun berbeda sangat nyata dengan perlakuan V1R0, V1R1, V1R2 dan V2R0.

Pengamatan berat gabah kering tertinggi ditunjukkan pada perlakuan V2R1 yang menunjukkan nilai rata-rata $1686,67 \mathrm{~g}$ yang berbeda tidak nyata dengan perlakuan V2R3 dan V1R2, tetapi berbeda sangat nyata dengan perlakuan V1R0 yang menunjukkan nilai ratarata terendah yaitu $1435,0 \mathrm{~g}$. Pengamatan berat gabah 1000 biji tertinggi ditunjukkan pada perlakuan V2R3 dengan nilai rata-rata $28,00 \mathrm{~g}$ yang berbeda tidak nyata dengan hampir semua perlakuan yang diujikan, tetapi berbeda sangat nyata dengan perlakuan V1R0 yang menunjukkan berat gabah 1000 biji terendah dengan nilai rata-rata 24,3 g. Hal ini membuktikan bahwa pemberian

Tabel 3.Pengamatan jumlah anakan tanaman padi pada setiap perlakuan

\begin{tabular}{cccc}
\hline \multirow{2}{*}{ Perlakuan } & \multicolumn{3}{c}{ Jumlah anakan } \\
\cline { 2 - 4 } & 2 MST & 4 MST & $6 \mathrm{MST}$ \\
\hline V1R1 & 6,8 & $13,9 \mathrm{~b}$ & $17,5 \mathrm{abc}$ \\
V1R2 & 6,7 & $13,3 \mathrm{~b}$ & $19,0 \mathrm{ab}$ \\
V1R3 & 6,5 & $17,8 \mathrm{a}$ & $19,3 \mathrm{ab}$ \\
V1R0 & 6,5 & $12,9 \mathrm{~b}$ & $16,5 \mathrm{abc}$ \\
V2R1 & 6,7 & $15,1 \mathrm{ab}$ & $20,0 \mathrm{a}$ \\
V2R2 & 6,6 & $15,3 \mathrm{ab}$ & $18,3 \mathrm{ab}$ \\
V2R3 & 6,9 & $14,3 \mathrm{~b}$ & $17,9 \mathrm{abc}$ \\
V2R0 & 6,1 & $13,0 \mathrm{~b}$ & $14,9 \mathrm{c}$ \\
\hline
\end{tabular}

Angka yang diikuti huruf yang sama pada kolom yang sama menunjukkan tidak berbeda nyata berdasarkan uji Duncan $\alpha=0,05, \mathrm{~V} 1=$ varietas IR64, V2 = varietas Cisantana, $\mathrm{R} 0=$ tanpa isolat rizobakteri, $\mathrm{R} 1=$ isolat P11a, $\mathrm{R} 2$ $=$ isolat PKLK5, R3 = kombinasi isolate P11a dan PKLK5. 
Tabel 4. Pengamatan jumlah hasil panen pada setiap perlakuan

\begin{tabular}{cccc}
\hline \multirow{2}{*}{ Perlakuan } & Jumlah ma lai & $\begin{array}{c}\text { Berat gabah kering panen } \\
(\mathrm{g})\end{array}$ & $\begin{array}{c}\text { Berat gabah } \\
1000 \mathrm{biji}(\mathrm{g})\end{array}$ \\
\hline V1R1 & $16,47 \mathrm{c}$ & $1505,00 \mathrm{bcd}$ & $27,67 \mathrm{ab}$ \\
V1R2 & $17,73 \mathrm{c}$ & $1603,67 \mathrm{ab}$ & $26,67 \mathrm{ab}$ \\
V1R3 & $23,67 \mathrm{ab}$ & $1556,67 \mathrm{bc}$ & $27,67 \mathrm{ab}$ \\
V1R0 & $16,2 \mathrm{c}$ & $1435,0 \mathrm{~d}$ & $24,30 \mathrm{~b}$ \\
V2R1 & $23,07 \mathrm{~b}$ & $1686,67 \mathrm{a}$ & $26,67 \mathrm{ab}$ \\
V2R2 & $25,40 \mathrm{a}$ & $1525,00 \mathrm{bcd}$ & $27,67 \mathrm{ab}$ \\
V2R3 & $21,80 \mathrm{~b}$ & $1683,33 \mathrm{a}$ & $28,00 \mathrm{a}$ \\
V2R0 & $17,9 \mathrm{c}$ & $1488,3 \mathrm{~cd}$ & $24,7 \mathrm{ab}$ \\
\hline
\end{tabular}

Angka yang diikuti huruf yang sama pada kolom yang sama menunjukkan tidak berbeda nyata berdasarkan uji Duncan $\alpha=0,05, \mathrm{~V} 1=$ varietas IR64, V2 = varietas Cisantana, $\mathrm{R} 0=$ tanpa isolat rizobakteri, $\mathrm{R} 1=$ isolat P11a, R2 $=$ isolat PKLK5, R3 = kombinasi isolate P11a dan PKLK5.

isolat rizobakter sangat berpengaruh terhadap hasil panen tanaman padi yang terserang $X$. oryzae pv. oryzae. Hasil ini juga mengindikasikan bahwa pencampuran dua isolat yang berbeda cenderung mampu meningkatkan hasil tanaman.

Serangan $X$. oryzae pv. oryzae pada tanaman padi yang menyebabkan penyakit HDB akan menghambat pertumbuhan pada tanaman padi, karena adanya pengurangan jumlah anakan yang berimplikasi terhadap pengurangan jumlah daun yang berpengaruh terhadap proses fotosintesis sehingga secara langsung menurunkan hasil panen melalui pengurangan jumlah malai yang terbentuk, berat gabah kering panen dan berat gabah 1000 biji. Namun dengan adanya pemberian rizobakteri, maka ketahanan tanaman dapat terinduksi sehingga mampu menghambat perkembangan patogen dalam jaringan tanaman.

\section{SIMPULAN}

Dari hasil penelitian ini dapat disimpulkan bahwa perlakuan rizobakteri mampu menginduksi ketahanan tanaman padi IR64 dan Cisantana terhadap Xanthomonas oryzae pv. oryzae di lapangan. Perlakuan campuran rizobakteri PKLK5 dan P11a, cenderung meningkatkan induksi ketahanan padi varietas IR64 terhadap Xanthomonas oryzae pv. oryzae, memperlihatkan pertumbuhan dan hasil panen yang lebih baik di lapangan dibandingkan perlakuan rizobakteri secara tunggal.

\section{DAFTAR PUSTAKA}

Agustiansyah. 2011. Perlakuan Benih untuk Perbaikan Pertumbuhan Tanaman, Hasil dan Mutu Benih Padi serta Pengendalian Penyakit Hawar Daun Bakteri dan Pengurangan Penggunaan Pupuk Fosfat. Tesis. Pasca Sarjana Institut Pertanian Bogor. (Tidak dipublikasikan).

Durrant WE \& Dong X. 2004. Systemic acquired resistance. Annu. Rev. Phytopathol. 42: 185209.

Hifni HR \& Kardin MK. 1998. Pengelompokkan isolat Xanthomonas oryzae pv. oryzae dengan menggunakan galur isogenik padi IRRI. Hayati 5: 66-72.

Hoerussalam, Purwantoro A, \& Khaeruni A. 2013. Induksi ketahanan tanaman jagung (Zea mays L.) terhadap penyakit bulai melalui seed treatment serta pewarisannya pada generasi S1. Jurnal Ilmu Pertanian 16(2): 42-59.

Keller B, Feuillet C, \& Messmer M. 2000. Genetics of disease resistance: Basic concepst and application in resistance breeding. In : Slusarenko AJ, Fraser RSS, \& Van Loon LC (Eds.). Mechanisms of Resistance to Plant Diseases.pp:101-160. Kluwer Academic Publisher. London.

Khaeruni A, Sutariati GAK, \& Wahyuni S. 2010. Karakterisasi dan uji aktifitas bakteri rizosfer lahan ultisol sebagai pemacu pertumbuhan tanaman dan agensia hayati cendawan patogen tular tanah secara in-vitro. J. HPT Tropika 10(2): 123-130. 
Khaeruni A \& Wijayanto T. 2013. Pathotype grouping of Xanthomonas oryzae pv. oryzae isolates from south Sulawesi and southeast Sulawesi. Agrivita 35(2): 138-144.

Khaeruni A, Wijayanto T, \& Syair. 2013. The utilization of indigenous rhizobacteria as an inducer for rice plant resistance against bacterial leaf blight disease (Xanthomonas oryzae pv. oryzae). In: Olanvoravuth N (Eds.). Proceeding the $8^{\text {th }}$ International Conference on Innovation and Collaboration Toward Asean Community 2015. pp. 30-36. Kendari Indonesia.

Nino-Liu DO, Ronald PC, \& Bogdanove AJ. 2006. Xanthomonas oryzae pathovars: Model pathogen of a model crop. Mol. Plant Pathol. 7(5): 303324.

Rahim, Khaeruni A, \& Taufik M. 2012. Reaksi ketahanan beberapa varietas padi komersial terhadap Xanthomonas oryzae pv. oryzae isolat Sulawesi Tenggara. Berkala Penelitian Agronomi 1(2): 132-138.
Rao KK, Jena KK, \& Narasu ML. 2003. Molecular Tagging of a New Bacterial Blight Resistence Gene in Rice Using RAPD and SSR Markers (Online) (http//dspace.irri.org-8080/dspce/bitstream/123456789/1308/1/Kameswara tagging. pdf. Diakses tanggal 15 Mei 2013.

Sticher L, Mauch-Mani B, \& Metraux JP. 1997. Systemic acquired resistance. Annu. Rev. Phytopathol. 35(1): 235-270.

Sutariati GAK. 2006. Perlakuan benih dengan agens biokontrol untuk pengendalian penyakit antraknosa, peningkatan hasil dan mutu benih cabai, cendawan patogen. Agriplus 15: 272-281.

Thakuria D, Talukdar NC, Goswami C, Hazarika S, Boro RC \& Khan MR. 2004. Characterization and screening of bacteria from rhizosphere of rice grown in acidic soils of Assam. Curr. Sci. 86(7): 978-985.

Van Loon LC, Bakker PAHM, \& Pieterse CMJ. 1998. Systemic resistance induced by rhizosphere bacteria. Annu. Rev. Phytopathol. 36: 453-483. 